https://doi.org/10.24101/logos.2020.50

Gauta 20200317

\title{
OKSANA NIKA
}

Taraso Ševčenkos Kijevo nacionalinis universitetas, Ukraina

Taras Shevchenko National University of Kyiv, Ukraine

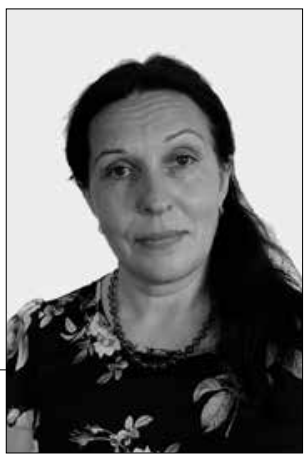

\section{LIETUVOS DIDŽIOSIOS KUNIGAIKŠTYSTĖS \\ CHARTIJOS VOLODYMYRO ROZOVO RANKRAŠČIŲ ARCHYVE: NAUJI ŠALTINIAI}

\author{
Charters of the Grand Duchy of Lithuania \\ in Volodymyr Rozov's Manuscript Archives: \\ New Sources
}

\begin{abstract}
SUMMARY
The article analyzes materials from the Archive 1 of V. Rozov. They contain knowledge important for modern historical linguistics and dialectology. The material is based on a deep and systematic study of charters from the fourteenth and fifteenth centuries, which Rozov made in publications of 1917 and 1928. Basically, the Archive comprises manuscripts written in the Kyiv period, as well as from 1925 to 1940, when V. Rozov taught at the universities of Skopje and Zagreb. New archival materials, which have not yet been the subject of a separate historical and linguistic study, reveal the expansion of the scientific concept of V. Rozov - from studying the phonetics of the Volyn dialect and the charters of Švitrigaila to a generalized presentation of the classification of business documents of the fourteenth and fifteenth centuries and dialectal differentiation of the language.
\end{abstract}

\section{SANTRAUKA}

Straipsnyje analizuojama V. Rozovo archyvo medžiaga, kurioje yra šiuolaikinei istorinei kalbotyrai ir dialektologijai svarbių duomenų. Tyrime pateikiamas gilus ir sistemingas XIV-XV a. chartiju, pateiktų 1917 ir 1928 m. leidiniuose, tyrimas. Archyvą sudaro rankraščiai, parašyti Kijevo laikotarpiu, taip pat laikotarpiu nuo 1925 iki 1940 m., kai V. Rozovas dėstẻ Skopjès ir Zagrebo universitetuose. Nauja archyvinė medžiaga, kuri dar nebuvo tirta nei istoriniu, nei kalbiniu požiūriu, atskleidžia $V$. Rozovo mokslinės minties raidą pradedant Voluinės tarmės fonetikos ir Švitrigailos chartijų tyrimais, baigiant apibendrinta XIV-XV amžių verslo dokumentu klasifikacija ir kalbos dialektine diferenciacija. 


\section{INTRODUCTION}

Volodymyr Rozov was a prominent scholar, researcher of charters of the fourteenth and fifteenth centuries, a linguist who made a significant contribution to the study of historical dialectology, linguistic source studies, onomastics, and language contacts. As a scholar, he had diverse scientific interests (linguistics, literature, philosophy, church history, cultural studies), was an active public figure. This proves the considerable stature of the scholar in the sociocultural context in the first half of the twentieth century and the need to demonstrate the relevance of his works for the contemporary scientific discourse.

$\mathrm{V}$. Rozov is often referred to as a scrupulous researcher of the original charters of the Grand Duchy of Lithuania as well as their publisher (Charters 1974; Ukrainian 1965; Volyn 1995; Litskevich 2009; Kupchynskyi 2004; Stančienė 2018; Grusha 2015: 28, et al.). Thus his publications of ancient monuments are highly rated in the works of famous linguists and historians of the twentieth and early twenty-first centuries: V. Demianchuk (Demianchuk 1928: 73-75), M. Bulakhov (Bulakhov 1978), M. Hrushevskyi (Hrushevskyi 2012), V. Rusanivskyi (Rusanivskyi 1965: 5).

The theoretical legacy of V. Rozov has not been as thoroughly explored and widely cited as his publications of charters of the Grand Duchy of Lithuania. Linguists seem to be much more familiar with his articles of the Kyiv period, when he lectured at St. Volodymyr University; it was during this period that the direction of V. Rozov's research ${ }^{2}$ began to shape. Our study is also devoted to the analysis of this period (Nika 2018). For the first time, the scholar presented his ideas in the article "The Importance of Charters of the Fourteenth and Fifteenth Centuries for the History of the Little Russian Language" (Rozov 1907b) (see review of the article by M. Hrushevskyi (Hrushevskyi 2012). After 1920, V. Rozov taught at the Theological Seminary of St. Savva in the town of Sremski Karlovci, later at the universities of Skopje and Zagreb (Sources 1931: 262-264; Kosik 2000: 250; Putiatin 2019: 327; PushkadiiaRybkina 2007: 179). As a leading Slavist of his time, V. Rozov took part in the First Congress of Slavists, which was held in Prague in 1929, making a presentation "More on Formulas TorT, TolT, TerT, TelT" (Sources 1931: 263).

The total number of studies authored by V. Rozov is "about 100 works on various issues of philology" (Bulakhov 1978: 168), some of which remained unpublished. The main works of the researcher are listed in reference books (Енциклопедія 1973; Bulakhov 1978; Peshchak 2000, Некрополь 2018: 211), articles and posts (Hrynchyshyn 1976; Zaleskyi 1969; Pliushch 1959; Nika 2018), and only some of them refer to V. Rozov's Archives.

The article is aimed at discussing the theoretical and applied aspects in the study of charters of the fourteenth and fifteenth centuries on the basis of V. Rozov's manuscript scientific legacy.

Importantly, the publication of charters provided V. Rozov with a factual input for writing fundamental works on linguistics, which explored the issues of historical dialectology, the influence of the Grand Ducal Chancellery language 
and local dialect features on the language of the charters under consideration. As we see from the Archives, to substantiate his conception, V. Rozov cites the works of A. Shakhmatov, E. Karsky, R. Brandt, Y. Rozvadovsky, V. Hantsov, K. Mykhalchuk, I. Zilynsky, L. Nie- derle, O. Brock, N. Durnovo, A. Sobolevsky and others, agreeing or arguing with the reputable scholars. The development of the historical and dialectological direction in his research is most fully represented by handwritten materials of the 1920s-30s from the Archives.

\section{VOLODYMYR ROZOV'S ARCHIVES}

V. Rozov's Manuscript Archives (RMA) consist of 9 folders, mostly handwritten (draft and final) works of the researcher; a significant number of these works are in Russian and Serbian. Inventory 2 indicates that this is a record group of permanent storage from 1925 to 1940.

Folder 1 of the Archives contains "South Russian Charters Ready for Publishing (and photographs to them)". According to the Archives Inventory, most of the works on linguistics (RMA, Folders 2-4) are devoted to the study of Volyn charters and, more broadly, to the language of Little Russian charters of the fourteenth and fifteenth centuries. Folder 4 features the unpublished "Index of Personal and Geographical Names" (a typescript). Together with the glossary to the charters, found in the same folder, it makes 116 pages.

Folders 5-7 (RMA) contain V. Rozov's works on history, literature, philosophy, church history written in Russian. Only one of them (Folder 7) contains materials for the study of Sanskrit: "Sanskrit (draft and unfinished passages). Sanskrit Grammar Course (unfinished) in 50 pages".

Folder 8 (RMA) contains works in Serbian.
The last folder contains the handwritten dictionary "Other Nouns with Substantive Roots (incomplete)" (50 p.) and the typescript of "The Language of South Russian Charters of the Fourteenth and Fifteenth Centuries" (Rozov 1929).

V. Rozov's Archives (RMA, Folder 4) also contain a separate item, "Printed Works of Prof. V. A. Rozov" (a typescript), which is an attempt to systematize the scholar's research. The list contains 32 works of the author, which are divided into periods: from 1907 to 1917 - 15 works, from $1924-17$ works. The last publication in the first period is the publication of the first volume of "South Russian Charters" compiled by V. Rozov (Rozov 1917).

The second period is represented by 12 works he wrote abroad in Russian, of which reviews make up a significant part (for example, reviews of the book by M. Weinghardt (1924), of the works by V. Pogorelov (1931). It is noteworthy that the main work on linguistics is "The Language of South Russian Charters of the Fourteenth and Fifteenth centuries." (reprint from the Proceedings of the Fourth Congress of Russian Academic Organizations Abroad (Rozov 1929). At the end of the list of V. Rozov's published works, we find his publications in Serbia in the Serbian language. Only a few 
works are given in the list with a note "and many reviews in the Serbian language in Serbian publications."

V. Rozov's publications list from the Archives is incomplete. His bibliography from 1921 to 1930 is much more accurately presented in the reference publication (Sources 1931: 262-264); most of the works it lists are in Serbian, including reviews. The scope of scientific publications is quite broad: the history of monasticism in Serbia, the Serbian manuscripts of Jerusalem and Sinai, the life of St. Savva and others. This list of works, particularly in Serbian, is fuller than the list from the Archives.

\section{THE CHARTERS OF THE FOURTEENTH AND FIFTEENTH CENTURIES PREPARED FOR PUBLISHING BY V. ROZOV}

It is known that V. Rozov prepared the charters of the fourteenth and midfifteenth centuries for publication in the second half of the nineteenth and the beginning of the twentieth century (Acts 1863, 1865; Archive 1883, 1867, 1890, 1893, 1907, 1909; Paleographic 1903; Collection 1884).

To study historical dialectology, V. Rozov turned to charters of the fourteenth and fifteenth centuries, which he termed "South Russian Charters". A certain simplification introduced by the publishers of the charters of the period had complicated the study of phonetics and spelling in particular, so the linguist began to examine the originals and collect texts from different archives and libraries.

Later, in the "Volyn Dialect" manuscript, he described the period of collecting materials for future publication as follows: “In 1905 and 1909, I went around all public and private bookstores and archives and partly photographed, partly copied all the charters published in the territory taken now by a Little Russian tribe, from the fourteenth century until 1625 " (RMA). Therefore, the initial chronological period, which was studied by V. Rozov, was longer and covered not only the fourteenth and fifteenth centuries, but also the sixteenth century and the first quarter of the seventeenth century. The linguist did not give the total number of charters collected by him during the period, but he mentioned that after the revolution there were about two hundred of them: "Most of them were lost during the revolution, but the rest give me an opportunity to work and prompt interesting conclusions because, fortunately, I have saved about two hundred charters from ancient times" (RMA).

The first edition of "South Russian Charters" (Rozov 1917) comprised 95 charters, which is almost half of the given number, and as it was designated the first volume, it presupposed continuation. Focusing on the tradition of publishing ancient texts, the linguist detailed the paleographic description of each charter and added a glossary at the end of the book.

The Kyiv-Pechersk Lavra printing house published a small print run of the first volume with a preface by V. Rozov. In the preface, the compiler expressed his gratitude to A. Sobolevsky and A. Shakhmatov for their support in exploring the texts under consideration (Rozov 1917; Ukrainian 1928). The sec- 
ond edition of charters appeared in 1928 with the second preface by A. Krymskyi (Ukrainian 1928).

The texts of V. Rozov have become an authoritative source cited by publishers of business documents. Thus M. Peshchak mentions there have been earlier editions of the charters, including V. Rozov's "South Russian Charters", "Ukrainian Charters", for example, such references are found in Charters 25, 27, 28, 41, $43,46,47,51$; some of them are reproduced according to the publication of V. Rozov (Charters 1974) as well as (Kupchynskyi 2004). A. Grusha cites Charter 7 - the Treaty of Prince Dimitry (Lubart) of Volyn with Casimir, the King of Poland, in his monograph (Grusha 2015: 28) according to the edition (Ukrainian 1928: 13-14). V. Rozov reckons Charters from the Lavrashev monastery among the South Russian Charters. Cf.: (Litskevich 2009).

Of particular value is the fact that V. Rozov paid maximum attention to collecting sources, the paleographic and linguistic study of which provided the basis for reliable conclusions and generalizations made not only for one genre of the South Russian Charters, but also determined the overall picture of the dialect differentiation of the South Russian language of the fourteenth and fifteenth centuries, its interaction with Belarusian, Lithuanian, Polish.

The practical value of the charters collected and described by V. Rozov is in the most accurate reproduction and thorough examination of each charter, supplemented by their photographs, which allows working with authentic texts and constitutes the empirical basis necessary for the research.

The preparation of charters for publication involved the compilation of a glossary and a list of personal and geographical names. The former was included in the publications of 1917 and 1928, while the latter remained unpublished and is found in the Manuscript Archives (RMA, Folder 4). The manuscript "Index of Personal and Geographical Names" is of particular interest, since it is a unique piece of information about the clans of the Grand Duchy of Lithuania, the names of land possessions given in the charters with an exact indication of the territory and time period. The "Index" is made up of anthroponyms in their reference to the territory and the social class of parties to legal actions recorded in the charters:

\footnotetext{
“быбелскии шляхетский род из переяславского округа...

быбыцкии домовладелец перемышльский

Бълики -

Бъдикъ, приближенный Свидригайла - : N. sg. Бъдикъ

Гирдивидъ - : N. sg. кгирдивид БЂдикъ

Семенъ, его сын - : N. sg. Семен" (RMA).
}

"Bybelsky, a noble family from Pereyaslav district

Bybytsky, a landlord from Peremyshl

Bieliki -

Bielik, a person from Švitrigaila's entourage -: N. sg. Bielik

Girdivid -: N. sg. Girdivid Bielik

Semen, his son - : N. sg. Semen (RMA) 
The anthroponym Гирдивидъ / Кгирдивид is of particular interest as it has a spelling variation of $\mathbf{r}-\mathbf{K r} \mathrm{dem}-$ onstrating the pronunciation of the backlingual $[r]$ in the charters as in the Lithuanian language. The "Index" lists one or two anthroponyms, as well as the titles: Поморскии панъ, один из титулов Ягелла - : N. sg. панъ поморскии.

The "Index" also contains the hydronyms and toponyms of the fourteenth and fifteenth centuries as well as their corresponding names at the beginning of the twentieth century. Some names were not explicated by V. Rozov; therefore, obviously, the "Index" was not included in the edition of "South Russian Charters":

“Быстрица, река Злота Быстрица, приток р. (не дописано, оставлено место).

Бытковичи теперь Бутковичи, село в перемышльском округе несколько на с.-в. от Перемышля" (RMA).

"Bystritsa, Zlota Bystritsa river, a tributary of the river (not finished, space left).

Bytkovichi, now Butkovichi, a village in the Peremyshl district, North-East of Peremyshl" (RMA).

The manuscript glossary is a unique source for studying the language in the period of the Grand Duchy of Lithuania, in particular, its onomastics, language interference and sociolinguistics. It was compiled on the basis of a careful examination of the originals and the establishment of various types of ties, kinship, social, territorial, etc., among the parties to the legal actions indicated in the charters. The glossary reflects the influence of the Grand Ducal Chancellery language and local dialect features.

As mentioned above, the manuscript "Other Nouns with Substantive Roots" is found in the last folder of the Archives. It is based not only on the material of the charters, but actually forms an etymological and historical dictionary, for example:

„Жалование (an allowance) /archaic/ 'monetary reward for the service'. The word derives from the verb жаловать (to grant), which is also archaic, meaning 'to show mercy, to reward, to give'.

The connection between the notions is explained historically: in Kyivan Rus, the service fee was officially considered the mercy shown by the tsar, a boyar and others. With the loss of such an implication, this connection was naturally broken.

From the etymological point of view, жаловать (to grant) originates from the group of жаль (pity), now unchanged predicative word, the verb жалеть (to pity) and related words.

The words of the latter group are not semantically associated with it: the idea of mercy does not now cause the idea of 'condolences'“ (RMA).

To the best of our knowledge, this dictionary has never been published. According to the title, this manuscript could be part of a lexicological study or a historical dictionary (Nika, Hrytsyna 2019).

\section{THE LANGUAGE OF THE CHARTERS OF THE FOURTEENTH AND FIFTEENTH CENTURIES}

The main linguistic research objective of V. Rozov was to explore the language of the South Russian charters of the four- teenth and fifteenth centuries. The development of his conception can be traced in the Manuscript Archives. From 
the chronology of the linguist's works, it is clear that the first draft and final manuscripts are entitled "Volyn Charters", which is further presented in the author's doctoral dissertation, where the study of Volyn charters is only part of the research and it complements the full picture of the dialect differentiation of the language of South Russian charters of the period.

To reconstruct V. Rozov's conception, it is important to note:

1. The motivation for the selection of the sources examined to accomplish the objectives. In the manuscript "Volyn Dialect", V. Rozov writes:

\begin{abstract}
"About twenty years ago, when I decided to study the ancient Little Russian dialectology, it was clear to me that the main attention should be paid to charters. Not to mention the fact that their language is in any case much richer in the vernacular and purely local features than the language of manuscripts of liturgical, religious and moral or even literary content. But the charters in the vast majority of cases have the exact date and an indication of the area where they are written, and this is extremely important when studying ancient dialectology" (RMA).
\end{abstract}

2. V. Rozov consistently uses the terms South Russian charters, Little Russian language, as well as Old Church Slavonic language. In the article of 1907, we also come across Ukrainian charters, Old Ukrainian language (Rozov 1907c: 30). In the second edition of the charters, the title is "Ukrainian Charters" (1928).

3. Expanding the chronological scope of the study. V. Rozov's publications of the charters, represent the texts of the fourteenth and the first half of the fif- teenth centuries; in the dissertation, this chronological period is expanded to the second half of the fifteenth and sixteenth centuries. This, in fact, is consistent with the original intention of collecting charters dated up to 1625 .

4. Extending the linguistic description of the charters. All manuscripts are not dated, but by the way the scholar expanded the material, we can conclude about the sequence of the manuscripts. Thus, the title page of one manuscript reads, "Volyn Charters. Phonetics" (84 p.). The following manuscript already contains an account of phonetics and morphology, "Volyn Charters. Phonetics. Morphology" (277 p.).

5 . The phonetic features of the texts under consideration provided the basis for distinguishing differential features and grouping charters according to the territorial principle ${ }^{3}$. This led to conclusions about the dialectic classification of the Little Russian (Ukrainian) language in the fourteenth up to the first half of the sixteenth centuries.

In the manuscript "Volyn Dialect", V. Rozov states that "...most of Švitrigaila's charters issued when he was the prince of Volyn have their own physiology, which sharply distinguishes them not only from South Russian, but also Russian charters in general" (RMA).

Among Volyn charters, he mentions 9 Švitrigaila's charters identical in language (Charters 69, 70, 74, 75, 82, 84, 85, $86,65)$. As V. Rozov further claims, one can also include "two charters of Lithuanian Prince Vytautas issued in Volyn (Charters 59, 61)" (RMA). In the linguist's opinion, "it is all the more remarkable that the documents of Vytau- 
tas, issued in different places, are always written following the language and spelling of the Lithuanian Grand Princely Chancellery" (RMA).

Among the texts of this genre of 1458-1540, the endowment charters from the Lavrashev monastery are inscribed in the Gospel of the fourteenth century: "some of them adhere to the same spelling, namely the charters of Pashko Obukhovich, Kotash Belikovich and Deshk Gavsovich. From my collection, we should also add to this group the agreement of Theodosius, the archbishop of Lavrashev, with Litavur, the Governor of Slonim, compiled in Lavrashev, May 16, 1492" (RMA). Even though the documents were created by different scribes, what they have in common is the fact of having been written in the same chancellery, so they share common spelling.

V. Rozov identified the places where the group of Švitrigaila's charters had been issued, namely in Volyn, as well as "in Kyiv, Slutsk, Slonim, Grodno, Belsk, and Mir" (RMA). In the manuscript, V. Rozov added Vilno. This may be a refinement, which the author added later, after writing the main text. There is no postscript in the published work: "one charter from each place: Kosher, Milenkovichi, Sklen, Slonim, Belsk, Grodno, Mir" (RMA 1929: 357).

In the work "The Language of South Russian Charters of the Fourteenth to Sixteenth Centuries", Volyn charters are presented most fully (36), of which: "2 of Great Pr. Vytautas, written in Volyn, 9 of Volyn Prince Švitrigaila, and of those written by other persons: 2 from Zhytomyr, 3 from Lutsk, 2 from Vladimir, 4 from Lavrashev, 5 from Kyiv, 4 from Slutsk and one from Kosher, Milenkovichi, Sklen, Slonim, Bielsk, Grodno, Mir" (RMA 1929: 357).

First, the linguist examines the charters of Švitrigaila, also referring those similar in language and spelling to the same group, which subsequently allows describing the main phonetic features of this group of the Grand Duchy of Lithuania (GDL) charters. V. Rozov identifies two of the most characteristic features inherent in Volyn vocalism which have been preserved in modern dialects: stressdependent alternations of $\mathbf{b}-\mathbf{e}$ and substitution of [a] after soft consonants.

The first one is the spelling of the letter $\mathbf{b}$ in a stressed syllable and its substitution with $\mathbf{e}$ in an unstressed position. The author associates phonetic differences with the spelling features: the diphthong is pronounced in a stressed syllable, and monophthong $\mathbf{e}$ is pronounced in unstressed positions.

We pay special attention to V. Rozov's assumption that the pronunciation of $\mathbf{b}$ is correlated with Lithuanian $\dot{\mathbf{e}}$, for example, in the name Algèrdas, Alkèrtas: "In some dialects, it is decomposed into ie with two equal constituents ... In others, such as East Lithuanian dialects ... it sounds as a sound close to i. Often just e sound is heard..." (RMA). This gives grounds for establishing the pronunciation "ie, or perhaps the pronunciation of the narrow e, close to $\mathbf{i}$, the spelling with $\boldsymbol{и}$ reflects this very pronunciation, and the spelling with e goes back to the Lithuanian forms with $\dot{e}^{\prime \prime}$ (RMA).

V. Rozov also associates some spellings of $\mathbf{b}$ in borrowed words with "the 
transfer of Polish é (acute e sound)", which had "in the fifteenth century, a diphthonic pronunciation" (RMA).

Rarely in the group of Volyn charters, there is the new $\mathbf{b}$, which is pronounced, according to V. Rozov, "in an unstressed syllable, as the old $\mathbf{b}-\mathbf{e}^{\prime \prime}$ (RMA).

Occasionally, the scholar notes the spelling of и instead of в (велили єсмио, видивb, etc.), which, however, he considers "formations with the suffix $\overline{\mathbf{1}}$ ", and refers their appearance to an earlier period, identifying them in the Laurentian and Hypatian Chronicles.

Thus, for the Volyn charters, the interpretation of all cases of the use of $\mathbf{b}$ and its substitutions is one of the most important differential features of the Volyn dialect.

The $\mathbf{b}$-options in the group of Švitrigaila's charters are systematized in more detail in the Index ${ }^{4}$. It includes the scheme and examples for analysis, namely:

„the stressed $\mathrm{b}$, obvious cases; $\mathrm{b}$ - more complicated cases; $\boldsymbol{i}$ in an unstressed syllable; $\mathrm{t}$ instead of the Polish é (acute sound e); e instead of the unstressed $\mathrm{b}$, obvious cases; e - more complicated cases; exceptions (е instead of $ь$ ); и instead of $\mathrm{b}$; e instead of the new unstressed $\mathrm{b}$; e instead of the new stressed $\mathrm{b}$; $\mathrm{b}$ in Charter 76; Living basis for the use of $\mathrm{b}$ in the Volyn charters" (RMA).

In later studies, V. Kurashkevich, Chr. Stang, M. Peshchak, V. Rusanivskyi, V. Nimchuk, V. Moisienko, I. Tsaralunga, et al. show the tendency to distinguish the spelling of $\mathbf{b}$ in a stressed syllable and e in an unstressed position in the charters of the fourteenth and fifteenth centuries (North Ukrainian and South Belarus).
The system of consonantism in the charters of Švitrigaila is characterized by the following features: 1) "bilabial w"; 2) "hardening of $\mathbf{r}$ is barely outlined"; 3) "there was no hardening of consonants before $\mathbf{e}$ and $\left.\mathbf{i}^{\prime \prime} ; 4\right)$ the presence of sound [f]; 5) soft sibilant sounds (spelling of ю after them), as well as "sibilant sounds retain their softness before $\mathbf{n}^{\prime \prime}$; 6) hardening of $[\mathrm{m}]$, in particular, at the end of the word and before the suffix -ьскыи: Беръдоховъскыи, горюховъскую, ивановьскому. However, "the spelling with ь кролевьскому, кролевьскым bеlongs to the charter that reveals a middle Bulgarian influence, moreover, in words borrowed from a foreign (Polish) language" (RMA); 7) the distinction of $/ \gamma /$ and /g/: Lithuanian explosive [g] is transmitted through the combination of $\mathbf{K r}$ (Швитрикгаилу), and "the pronunciation of $\mathbf{r}$ as a spirant ... can be seen from omitting it in wcnodapю" (RMA).

The group of Volyn charters is one of the three groups singled out by V. Rozov. The other two are:

- the Galician group (28 charters), the main difference of which is the alternation of $\mathbf{b}-\mathbf{n}$, the new $\mathbf{b}$, as well as $\mathbf{y}, \mathbf{1}$ in new closed syllables, etc.

- some charters of Bukovinian-Moldovan origin, which have a common feature of "an extremely frequent alternation of $\mathbf{b}$ through $\boldsymbol{и}$ and equally frequent alternations of $\mathbf{m}$ and $\mathbf{n}$, which leaves no doubt that the scribes pronounced $\mathbf{b}$ as $\mathbf{i}$ and did not distinguish between $\mathbf{ы}$ and и" (RMA 1929: 392).

Researchers of the documents of the fourteenth and fifteenth centuries put the last two groups together on the basis 
of the alternation of $\mathbf{\mathbf { b }}-\mathbf{\mathbf { n }}$, noting its regularity for the Moldovan charters: "Moldovan charters consistently and Galician charters sporadically reflect the continuity of $*$ ě $>i$, which can be considered an influence of the South Ukrainian vernacular" (Carałunga 2016: 172). Thus, the main trend is the separation of the two dialect zones, the North and South Ukrainian.

At the same time, the groups of charters in the fourteenth and fifteenth centuries distinguished by V. Rozov correspond to three dialects: Middle Russian dialect (or Volyn, which is transitional from South Belarussian to North Ukrainian) and two South Russian dialects: Old Galician and Old Ukrainian (RMA 1929: 392).

V. Rozov tries to relate his conclusions to the ancient settlement of the tribes mentioned in the Chronicles: the first dialect was spread in the territories of the former Polians, Drevlians, Volynians, Dulibs and Buzhans, Dregovichs, and possibly Severians, the second - white Croats, and the third - Ulichs and Tivertsi.

For Rozov, the perspective of the results obtained in accordance with the modern dialect map is relevant: "the Eastern Ukrainian dialect is a direct descen- dant of the dialect of Ulichs and Tivertsi, the Western Ukrainian and Carpathian dialects appeared as a result of combining it with the Old Galician, and the Northern Little Russian dialect is the result of mixing the Eastern Ukrainian and partly Western Ukrainian dialects with the Old Volyn dialect" (RMA 1929: 392).

Diachronically and synchronically, V. Rozov distinguishes three dialects of the "Little Russian" (Ukrainian) language, which could have changed historically since the fourteenth and fifteenth centuries. These views of the author should be compared with the approaches to the differentiation of two dialects in the GDL, as well as the formation of three dialects after the GDL. V. Rozov's studies broaden knowledge on historical dialectology and history of the language, and also the approaches to a number of issues that have already become a certain tradition. Thus, V. Rozov clarifies A. Sobolevsky's description of the Galician-Volyn phonetic and spelling features, terming them Galician; casts doubt on the statements of A. Shakhmatov about the transition of $\mathbf{e}$ to $\mathbf{o}$ after $\mathbf{j}, \boldsymbol{ж}, \mathbf{4 , ~} \mathbf{ш}, \mathbf{щ}, \mathbf{\text { and }}$ about later e by analogy; disagrees with V. Hantsov in the understanding of the diphthong [üö] and others.

\section{CONCLUSIONS}

The publications of charters from the Grand Duchy of Lithuania were the result of a paleographic and linguistic description of only part of the documents that V. Rozov had collected, and the "Index of Personal and Geographical Names" as a supplement still remains unpublished. V. Rozov's Archives recreate the development of his conception, from studying the charters of Švitrigaila and the Volyn dialect to the systematization of three dialect zones in the fourteenth and fifteenth centuries. Unreleased materials on linguistics from the Archives 
demonstrate the linguist's theoretical understanding of the phonetic and morphological organization of the charters, the principles of their grouping, language

\section{References}

Acts relating to the history of Southern and Western Russia, collected and published by the Archaeographic Commission, 1863. Акты, относящиеся к истории Южной и Западной России, собранные и изданные Археографической комиссией, 1863 Т. 1 (1361-1598). Санкт-Петербург; 1865. T. II (1599-1637). Санкт-Петербург.

Archive of South-West Russia, published by the Provisional Commission for the analysis of ancient acts, the highest established under the Kyiv, Podillia and Volyn governor-general. 1883. - Архив Юго-Западной России, издаваемый Временной Комиссией для разбора древних актов, высочайше учрежденной при Киевском, Подольском и Волынском генерал-губернаторе 1883. Ч. 1. Т. VI, Киев; 1867. Ч. 4. Т. 1, Киев; 1890. Ч. 7. Т. ІІ, Киев; 1893. Ч. 8. Т. 1, Киев; 1909. Ч. 8, Т. ІІІ, Киев; 1907. Ч. 8, T. IV, Киев.

Bulakhov Mikhail G. 1978. - Булахов Михаил Г. 1978. Розов Владимир Алексеевич [Vladimir Alekseyevich Rozov], Булахов М. Г. Восточнославянские языковеды. Т. 3. Минск: 167-168.

Carałunga Inna. 2016. Рефлекси праслов'янського *е̌ у мові українських грамот XIV ст. [Reflexes of the Slavic *ě in the language of Ukrainian charters of the fourteenth century]. Slavia Orientalis. T. LXV, nr 1: 161-172.

Charters of the fourteenth century. 1974. - Грамоти XIV ст. 1974. Упорядк., вст. ст., ком. і слов.-покаж. М.M. Пещзак. Київ: Наукова думка: 256.

Collection of paleographic recordings of ancient charters and acts stored in the Vilnius Central Archives and the Vilnius Public Library. 1884. Сборник палеографических снимков древних грамот и актов, хранящихся в Виленском Центральном архиве и Виленской Публичной библиотеке. 1884. Вып. 1 (1432-1548). Вильна: VIII+45+XXX.

Demianchuk Vasyl. 1928. - Дем'янчук Василь. 1928. Морфологія українських грамот XIV-го і першої половини XV-го віку [Morphology of interaction, correlation of the diachronic and synchronic dialectology data, which can be reconsidered in contemporary linguistic research.

Ukrainian charters of the fourteenth and first half of the fifteenth century], Записки історично- $\phi i$ лологічного відділу УАН. Київ. Кн. 16: 73-109.

Dictionary of Old-Ukrainian language of the fourteenth and fifteenth centuries. 1977-1978. - Словник староукраїнської мови XIV-XV ст. 19771978. Ред. кол.: Д. Г. Гринчишин, А. А. Гумецька (голова), І. М. Керницький. Київ: Наукова думка, Т. 1-2.

Garbul Liudmila. 2009. - Гарбуль Дюдмила. 2009. Семантические полонизмы в русском приказном языке первой половины XVII века [Semantic polonisms in the Russian command language of the first half of the seventeenth century] Докторская диссертация. Гуманитарные науки, филология (04 H). Вильнюс. <file:///C:/Users/Blue/AppDatal Local/Temp/1869170.pdf>. [accessed on 201902 03].

Grusha Aleksandr I. 2015. - Груша Александр И. 2015. Деловая письменность Великого Княжества Аитовского (конец XIV - первая треть XVI в.) [Business writing of the Grand Duchy of Lithuania (end of the fourteenth - the first third of the sixth century]. Минск: Беларуская навука: 465.

Hantsov Vsevolod. 1923. - Ганцов Всеволод. 1923. Діялектологічна класифікація українських говорів (з картою) [Dialectological classification of Ukrainian dialects (with map)]. Київ: Видавництво Української АН: 67.

Hantsov Vsevolod. 1923. - Ганцов Всеволод. 1923. Характеристика поліських дифтонгів і шляхи ïх фонетичного розвитку [Characteristics of Polissia diphthongs and ways of their phonetic development], Записки історико-філологічного відділу УАН. Київ. Кн. 2-3: 116-144.

Hantsov Vsevolod. 1926. - Ганцов Всеволод. 1926. До історії звуків в українській мові [On the history of sounds in the Ukrainian language], Записки історико-філологічного відділу УАН. Київ. Кн. 7-8: 74-85.

Hrushevskyi Mykhailo S. 2012. - Грушевський Михайло С. 2012. В. А. Розов. 1907. Значение 
грамот XIV и XV веков для истории малорусского языка [The value of charters of the fourteenth and fifteenth centuries for the history of the Little Russian language]. К., стор. 20 (відб. 3 "Унив. известий" київських). Грушевський Михайло С. Твори: у 50 m., П. Сохань (голов. ред.), І. Гирич та ін. Аьвів: Видавництво “Світ". Т. 16: 102-103.

Hrynchyshyn Dmytro. 1976. - Гринчишин Дмитро Г. 1976. Володимир Олексійович Розов [Volodymyr Oleksiiovych Rozov], Мовознавство, 5: 89-91.

Kosik Viktor I. 2000. - Косик Виктор И. 2000. Русская Церковь в Югославии (20-40-е гг. XX века) [Russian Church in Yugoslavia (20-40s of the twentieth century)]. Москва: Православный Свято-Тихоновский богословский институт: 287.

Kupchynskyi Oleh. 2004. - Купчинський Олег. 2004. Акти та документи Галицько-Волинського князівства XIII - першої половини XIV стоиіть. Дослідження. Тексти [Acts and Documents of the Principality of Galicia and Volyn in the thirteenth - the first half of the fourteenth centuries. Research. Texts]. Аьвів: 1285.

Kuraszkiewicz Władysław. 1934. Gramoty halicko-wołyńskie XIV-XV wieku. Studjum językowe [The charters of Galicia and Volyn of the fourteenth and fifteenth centuries. A language study]. Kraków: 174.

Litskevich Aleh. 2009. - Ліцкевіч Алег У. 2009. Старабеларускія граматы XV ст. $з$ Archiwum głównego akt dawnych y Варшаве [Old Belarusian charters of the fifteenth century from the Archiwum głównego akt dawnych in Warsaw], Здабыткі. Дакументальныя помнікі на Беларусі. Вып. 11. Минск: 6-41.

Matviienko A.V. Матвієнко A.M. Передмова [Preface], Волинські грамоти XVI cm. 1995. Упоряд. В. Задорожний, А. Матвієнко. Київ: Наукова думка: 5-16. (Пам'ятки української мови XVI ст.: серія актових документів і грамот).

Moisiienko Viktor M. 2006. - Мойсієнко Віктор M. 2006. Фонетична система українських поліських говорів у XVI-XVII ст. [Phonetic system of Ukrainian Polissya speeches in sixteenth and seventeenth centuries]. Житомир: Видавництво Житомирського державного університету ім. І. Франка: 450.

Moisiienko Viktor M., Nika Oksana I. 2013. - Мойсієнко Віктор М., Ніка Оксана I. 2013. “Проста мова" в Україні та Білорусі XVI ст. ["Simple speech" in Ukraine and Belarus in the sixteenth century]; О.С. Онищенко (голова ред.). Київ: НБУВ: 25.

Moldavan Aleksandr V. 2000. - Молдаван Александр М. 2000. Пять новонайденных украинских грамот конца XIV-начала XV в. [Five newly found Ukrainian charters of the late fourteenth - early fifteenth century], Аингвистическое источниковедение и история русского языка. Москва: Аревлехранилище: 261-276.

Nika Oksana I. 2018. - Ніка Оксана I. 2018. Розов Володимир Олексійович в історії Університету Святого Володимира [Volodymyr Oleksiiovych Rozov in the history of St. Volodymyr's University], Українське мовознавство. Вип. 1(48): 64-75.

Nika Oksana, Hrytsyna Svitlana. 2019. Frequency Dictionary of 16th Century Cyrillic Written Monument. Jazykovedný časopis. Roč. 70, č. 2: 276-288.

Paleographic photographs from Russian charters mainly of the fourteenth century. 1903. - Палеографические снимки с русских грамот преимущественно XIV века. 1903. Издание С.-Петербургского археологического института; под. ред. А.И. Соболевского и С.А. Пташицкого. Санкт-Петербург: 12+51.

Peshchak Maria M. 1979. - Пещак Марія М. 1979. Стиль ділових документів XIV ст. : структура тексту [The style of business documents of the fourteenth century: text structure]. Київ: Наукова думка: 268.

Peshchak Maria M. 2000. - Пещак Марія М. 2000. Розов Володимир Олексійович [Volodymyr Oleksiiovych Rozov], Украӥнська мова: Енцииклопедія. Київ: Українська енциклопедія ім. М.П. Бажана: 523.

Pliushch Pavlo P. 1959. - Плющ Павло П. 1959. Перший викладач історії української мови в Київському університеті (Про педагогічну і наукову діяльність проф. В.О. Розова у зв'язку з 125 річчям КДУ) [The first teacher of history of the Ukrainian language at the University of Kyiv (About pedagogical and scientific activity of Prof. V.O. Rozov in connection with the 125 anniversary of KSU)], Вісник Київського університету: Серія філологіі та журналістики. Ч. 2. Вип. 2: 142-150.

Pushkadiia-Rybkina Tatiana V. 2007. - ПушкадияРыбкина Татьяна В. 2007. Эмигранты из России в научной и культурной жизни Загреба [Emigrants from Russia in the scientific and cultural life of Zagreb]. Загреб: 340. 
Putiatin Vladimir S. 2019. - Путятин Владимир C. 2019. Филолог-славист С.М. Кульбакин и другие российские профессора Философского факультета в Скопье в 20-30-е годы XX в. [Philologist Slavic S.M. Kulbakin and other Russian professors of the Faculty of Philosophy in Skopje in the 20-30s of the twentieth century], Столетие двух әмиграций. 1919-2019, ред. кол.: А.Ю. Тимофеев (отв. ред.), А.А. Силкин, В.С. Путятин, М. Живанович. Москва: Институт славяноведения РАН; Белград: Информатика: 311-332.

Rozov Alexei Vasilievich. 1907a. - Розов Алексей Васильевич. 1907а. Эничиклопедический словарь Брокгауза и Ефрона [Brockhaus and Efron Encyclopedic Dictionary]: 82 и 4 доп. тома; Санкт-Петербург, T. II a: 547.

Rozov Vladimir. 1907b. - Розов Владимир. 1907b. Значение грамот XIV и XV веков для истории малорусского языка [The value of charters of the fourteenth and fifteenth centuries for the history of the Little Russian language]. Киев: 20 (відб. 3 “Университетских известий”).

Rozov Vladimir. 1917. - Розов Владимир. 1917. Южнорусские грамоты [South-Russian charters]. Киев: Типография Киево-Печерской лавры, Т. 1: 261. Издание Отделения русского языка и словесности Академии наук.

Rozov Vladimir. 1928. - Розов Владимир. 1929. Язык южнорусских грамот XIV - XVI вв. [The language of South-Russian charters of the fourteenth and fifteenth centuries]. Белград: Издание Русского научного института в Белграде, С. Оттиск из: Труды IV съезда русских академических организаций за границей. Ч. 1.

Rozov Volodymyr Oleksiiovych. Розов Володимир Олексійович. 2018. Некрополь філолологів - викладачів Київського Свято Володимирового та Шевченкового університету: біографічний довідник [Necropolis of philologists-teachers of the Kyiv St. Volodymyr and Shevchenko University: biographical guide] / за ред. Г.Ф. Семенюка. Київ: Логос: 291.

Rozov Volodymyr Розов Вододимир. 1973. Енциклопедія українознавства. Словникова частина. Париж, Нью-Йорк, Т. 7, 11. <http://litopys. org.ua/encycl/euii194.htm>. [accessed on 2018 10 03].

Rozov Volodymyr. 1907c. - Розов Володимир. 1907с. До старо-руської діялєктольогії: (іще до питання про галицько-волинське наріче) [On Old-Russian Dialectology: (and on the Ques- tion of the Galician-Volyn Dialect)], Записки Наукового Товариства ім. Шевченка. T. LXXVII: 30. (окремий відбиток).

Rozov Volodymyr. 1928. - Розов Володимир. 1928. Українські грамоти. Т. 1. XIV і перша половина XV ст. [Ukrainian charters. Book 1. Fourteenth and first half of fifteenth century]. Київ: Друкарня Української Академії Наук: $4+176+75+\mathrm{IX}$.

Rusanivskyi Vitalii M. 1965. - Русанівський Віталій М. 1965. Передмова, Украйнські грамоти XV cm., підготовка тексту, вступна стаття і коментарі В.M. Русанівського [Foreword, Ukrainian charters of the fifteenth century, preparation of the text, introductory article and comments by V. M. Rusanivskyi]. Київ: Наукова думка: 5-23. (Пам'ятки української мови: серія юридичної літератури).

Rusanivskyi Vitalii M. 2001. - Русанівський Віталій М. 2001. Історія украӥнської літературної мови [History of Ukrainian literary language]. Київ: АртЕк: 392.

Sources for bibliography of Russian scientific works abroad: 1920-1930. 1931. - Материалы для библиографии русских научных трудов за рубежом: 1920-1930. 1931. Белград: Издание Русского Научного Института в Белграде, Вып. 1: 384.

Stang Christian S. 1935. Die westrussische Kanzleisprache des Grossfürstentums Litauen [The West-Russian chancellery language of the Grand Duchy of Lithuania]. Oslo: 148.

Stankiewicz Jan. 1936. Stang, Chr. S. 1935. Die westrussische Kanzleisprache des Grossfürstentums Litauen [The West-Russian chancellery language of the Grand Duchy of Lithuania]. Oslo, Balticoslavica, 2, Wilno: 374-398.

Stančienė, Dalia Marija. 2018. Brandžiųjų viduramžių scholastinė filosofija = Scholastic philosophy in the high middle ages. Logos 94: 55-62.

Ukrainian charters of the fifteenth century, preparation of the text, introductory article and comments by V.M. Rusanivskyi. 1965. - Українські грамоти XV ст. 1965. Підготовка тексту, вступна стаття і коментарі В.М. Русанівського. Київ: Наукова думка: 164. (Пам'ятки української мови: серія юридичної літератури).

Volyn charters of the sixteenth century. Волинські грамоти XVI ст. 1995. Упоряд. В. Задорожний, А. Матвієнко. Київ: Наукова думка: 245. (Пам'ятки української мови XVI ст.: серія актових документів і грамот). 
Wojtkowiak Zbysław. 1978. Грамоти XIV ст. [Charters of the fourteenth century]. 1974. Упорядкування, вступна стаття, коментарі і словники-покажчики M.M. Пещак, Київ, Studia Zródloznawcze, 23, Warszawa, Poznan: 213-216.

\section{Endnotes}

1 The archive fund of Professor Volodymyr Oleksiiovych Rozov, which mainly includes manuscripts in Russian, Serbian and other languages, is kept at the O.O. Potebnia Institute of Linguistics of the NAS of Ukraine (Kyiv, Ukraine). We express our gratitude to the leadership of the Institute of Linguistics for their help in studying these materials for the preparation of the article. All archival documents used are cited with reference to this source (hereinafter - RMA).

2 If we talk about scientific traditions, then his father, professor Oleksii Vasyliovych Rozov, is "a writer, a graduate of the Kyiv Theological Academy, where he holds the position of Professor of Modern World Secular History. His main work is entitled "Christian Nubia. Part I. Sources for
Zaleskyi А. 1969. - Залеський Антон М. 1969. Нові надходження до архіву Інституту імені О.О. Потебні АН УРСP [New additions to the archive of the O.O. Potebnia Institute of the USSR Academy of Sciences.]. Мовознавство. 3: 36.

the history of Christianity in Nubia" (Kyiv, 1890, doctoral dissertation)" (Rozov 1907a: 547).

${ }^{3} \mathrm{~V}$. Rusanivskyi divides the charters of the fifteenth century into five groups: "1) charters of Central Ukraine, 2) charters of Western Polesie, 3) charters of Galicia, 4) charters of Moldova, 5) Transcarpathian charter" (Rusanivskyi 1965: 10). Of these, the Charters of Western Polesie and Moldova are most fully represented.

${ }^{4}$ A separate document in the manuscript - Index of doctoral dissertation of Prof. V. A. Rozov "The Language of South Russian Charters of the Fourteenth Century". The postscript on the title page of the manuscript reads, "he defended his thesis on 7.01.1928 in the city of Ljubljana in Yugoslavia" (RMA). 